\title{
USE OF SWEETENERS IN OSMOTIC PRETREATMENT BEFORE FREEZE-DRYING OF PEAR AND PINEAPPLE
}

\author{
M. Wlodarczyk-Stasiak*, A. Mazurek, J. Jamroz, U. Pankiewicz and R. Kowalski \\ Department of Analysis and Evaluation of Food Quality, Faculty of Food Science and Biotechnology, \\ University of Life Sciences in Lublin, Skromna Street 8, 20-704 Lublin. Poland
}

(Received: 31 January 2018; accepted: 26 July 2018)

\begin{abstract}
The aim of the study was to analyse the influence of the type of osmotic substance (sucrose, glucose, xylitol, trehalose, and sorbitol) on the physicochemical properties of freeze-dried fruit (pear and pineapple). Controlling the functional properties of freeze-dried fruit after osmotic dehydration with aqueous solutions at water activity of $\mathrm{a}=0.90$ is presented. Decrease in the water adsorption index (WAI) was recorded for all dehydrated samples. The largest decrease (for pears and pineapples by 25 and $65 \%$, respectively) was observed in osmoactive solutions containing trehalose. Considerable increase in the FAI was recorded in samples of dehydrated pineapple. In osmoactive trehalose solutions that increase hardly reached $46 \%$, whereas in sorbitol and xylitol its value elevated to $39 \%$ and $13 \%$, respectively. Regardless of the osmoactive sweetener applied prior to freeze-drying, an increase in specific surface area $\left(\mathrm{S}_{\mathrm{BET}}\right)$ of dried materials was observed. For dehydrated pears, $\mathrm{S}_{\mathrm{BET}}$ ranged from 96 to $697 \mathrm{~m}^{2} \mathrm{~g}^{-1}$, and for pineapple, from 115 to $938 \mathrm{~m}^{2} \mathrm{~g}^{-1}$. Osmotic dehydration before lyophilisation of fruit samples weakened rehydration relative to the control. The dehydration carried out with osmoactive sweeteners, that is, sorbitol, xylitol, and trehalose, allows obtaining a product with good functional properties that can be successfully used for supplementation of dietary products, in particular for diabetics.
\end{abstract}

Keywords: freeze-drying, functional properties, osmotic dehydration, pear, pineapple, sweeteners

Osmotic dehydration, as a method of food preserving, establishes a basis for maintaining desired sensory characteristics and nutritional value of food products. Osmotic dehydration takes place in hypertonic solutions; water from tissues of raw material penetrates a highconcentration solution and osmoactive components diffuse into the tissues (MouRA et al., 2005).

The degree of dehydration of a material depends on the concentration of the osmoactive component in the solution, particle size of raw material, its weight to solution volume ratio, temperature, and duration of the process. Soluble chemicals of low molecular weight are the most frequently used osmoactive compounds (MARANI et al., 2007).

Osmoactive solutions containing sodium chloride are used for dehydrating vegetables, while fructose, glucose, sucrose, and corn syrup are applied to fruit (MARANI et al., 2007; CIURZYŃSKA \& LENART, 2010a). Osmoactive solutions reduce the activity of phenolic oxidase and prevent anthocyanin pigments from oxidation (PęKOSŁaWsKA-GarstKa \& LenART, 2010).

Lowering the water activity within the material restricts the growth of microorganisms, but does not provide its desired stability. Osmotically dehydrated raw material can be considered as a semi-product prepared for subsequent technological processes such as drying, freeze-drying, or freezing (KOPERA \& MiteK, 2007).

\footnotetext{
* To whom correspondece should be addressed. Phone: +48 8146233 31; e-mail: marzena.stasiak@up.lublin.pl
} 
Osmotic dehydration preceded by freeze-drying is an alternative method of food preservation. Water removal by means of sublimation preserves the nutritional value of the product, because enzymatic reactions and processes of non-enzymatic browning are either suppressed or completely inhibited. Low temperature processes are beneficial for preserving natural flavours and aromas, which usually are lost in the case of conventional drying (Shishehgarha et al., 2002; Kopera \& Мitek, 2007).

Freeze-dried materials develop a porous structure, which determines strong rehydration capability. The rehydration index for freeze-dried products is up to six times higher than that for dried materials prepared with traditional methods (HAMmAMI \& RENE, 1997).

Freeze drying is an expensive drying technique compared to drying with hot air. However, due to the superior qualitative characteristics and nutritional value of the lyophilized product, it is more and more used for food production. The products of freeze drying (lyophilized food) are very popular among consumers of healthy food, with no conservatives, as a natural supplement that gives flavour to protein supplements.

The aim of this study was to analyse the influence of the type of osmotic solutions of sucrose, glucose, xylitol, trehalose, and sorbitol on selected physicochemical and functional properties of freeze-dried pear and pineapple.

\section{Materials and methods}

\subsection{Materials}

Pineapples and pears cv. Conference were purchased from the local market. The fruit were pre-processed by washing, peeling, removing inedible parts, in the case of pears - the seeds and stems. Fruit preprepared in this manner were cut into $1 \mathrm{~cm}^{3}$ cubes.

\subsection{Methods}

1.2.1. Osmotic dehydration. Aqueous solutions of either glucose, sucrose, trehalose, xylitol, or sorbitol, with water activity $\left(\mathrm{a}_{\mathrm{w}}\right) \sim 0.90$ (Table 1 ), were prepared. The cubes of fruit $(100 \mathrm{~g}$ ) were immersed in a solution at a weight ratio of 1:4 (g fruit/g osmoactive solution). The thermostated blends in flasks were shaken at $30^{\circ} \mathrm{C}$ for $3 \mathrm{~h}(200 \mathrm{r}$.p.m.), then allowed to drain and, finally, frozen at $-22{ }^{\circ} \mathrm{C}$ for 24 hours (Comesan et al., 2001; CiurzyńsKa \& LenART, 2010a).

Table 1. Physicochemical and physiological properties of the osmoactive substances

\begin{tabular}{lccccc}
\hline & \multicolumn{5}{c}{ Osmoactive substances } \\
\cline { 2 - 6 } & Trehalose & Xylitol & Sorbitol & Glucose & Sucrose \\
\hline $\begin{array}{l}\text { Concentration of the solution } \\
(\mathrm{g} / 100 \mathrm{~g}) \text { in } \mathrm{a}_{\mathrm{w}} \sim 0.90\end{array}$ & 50.0 & 35.5 & 45.0 & 49.2 & 61.5 \\
Molar mass $\left(\mathrm{g} \mathrm{mol}^{-1}\right)$ & 342 & 152 & 182 & 180 & 342 \\
\hline
\end{tabular}

1.2.2. Freeze-drying. Samples were lyophilized in the Labconco FreeZone 6 apparatus (Kansas City, USA) under $133 \times 10^{-3} \mathrm{mBar}$, at $-46^{\circ} \mathrm{C}$ collector temperature. The freeze-dried fruits were ground and passed through a screen. Fractions below $0.63 \mathrm{~mm}$ particle size were 
collected for further study. Lyophilisation was carried out to obtain a water content not exceeding $6 \%$. Fruit control samples were not osmotically dehydrated but only lyophilized.

1.2.3. Water absorption index (WAI) and water solubility index (WSI). Determination of the water absorption index and aqueous solubility index was performed according to ANDERSON and co-workers (1969).

1.2.4. Fat absorption index. Fat absorption index was determined according to RutKowski and KozŁowsKa (1981).

1.2.5. Specific surface area $\left(S_{B E T}\right)$. Water vapour adsorption measurements and specific surface area was determined according to RÜEGG (1980) and WŁODARCZYK-STASIAK \& JAMROZ (2008).

1.2.6. Sorption curves. Freeze-dried fruit were dried to a constant weight and was placed in desiccators with water activities $\mathrm{a}_{\mathrm{w}}=0.63$ and 0.93 , at $25^{\circ} \mathrm{C}$ (RüEGG, 1980). Measurements were made on average every 2 days until the equilibrium moisture of the samples was reached (CiURZYŃSKa et al., 2013).

1.2.7. Rehydration. Freeze-dried fruit were subjected to rehydration at $20^{\circ} \mathrm{C}$. Samples $(1 \mathrm{~g})$ were left in water $(20 \mathrm{ml})$ for $5,30,60,90$, or $120 \mathrm{~min}$, and then the material was filtered and weighed. The relative increase in the material weight was determined based on $1 \mathrm{~g}$ of freeze-dried material (RZĄCA \& Witrowa-RAJCHERT, 2007).

1.2.8. Statistical analysis. The data reported as results are an average of triplicate observations. The mean values $(\mathrm{x})$ and the standard deviation $(\sigma)$ were calculated from the range $(x-2 \sigma ; x+2 \sigma)$. ANOVA was used to calculate significant differences in treatment means and LSD $(\mathrm{P}<0.05)$.

\section{Results and discussion}

Water solubility index of the freeze-dried pears and pineapples after osmotic dehydration was dependent on the type of fruit. The same treatment applied to pineapple significantly changed WSI in respect to control, but again the identity of the sweetener applied was insignificant (Fig. 1). Osmotic dehydration applied as a pretreatment resulted in an increase in WSI as compared to not osmotically dehydrated lyophilizates. Lewicki and Lenart (2007), who osmotically dehydrated lyophilized strawberries, observed that lyophilizates became more resistant to rehydration, absorbed less water vapour, and were less water soluble. That could result from the saturation of the fruit surface with osmoactive compound, limiting interaction with water. However, the results of the study by LEWICKI and LENART (2007) do not correlate with those presented in this work. Regardless of the osmoactive compound applied, the freeze-dried pineapple was better soluble than the control sample. Likely, fragmentation of freeze-dried fruit and, hence, better availability of the hydration sites and penetration could be responsible for that. PękosŁanska-Garstka and Lenart (2010), studying osmotic dehydration of pumpkin flesh, observed that penetration of osmoactive compounds inside dehydrated material depended on the molecular weight of the osmoactive compounds. 
Glucose more readily penetrated pumpkin flesh than corn syrup, as it has a lower molecular weight. The thesis that the penetration of osmoactive compounds inside dehydrated material depends on the molecular weight of the osmoactive compound has found confirmation in our own research.

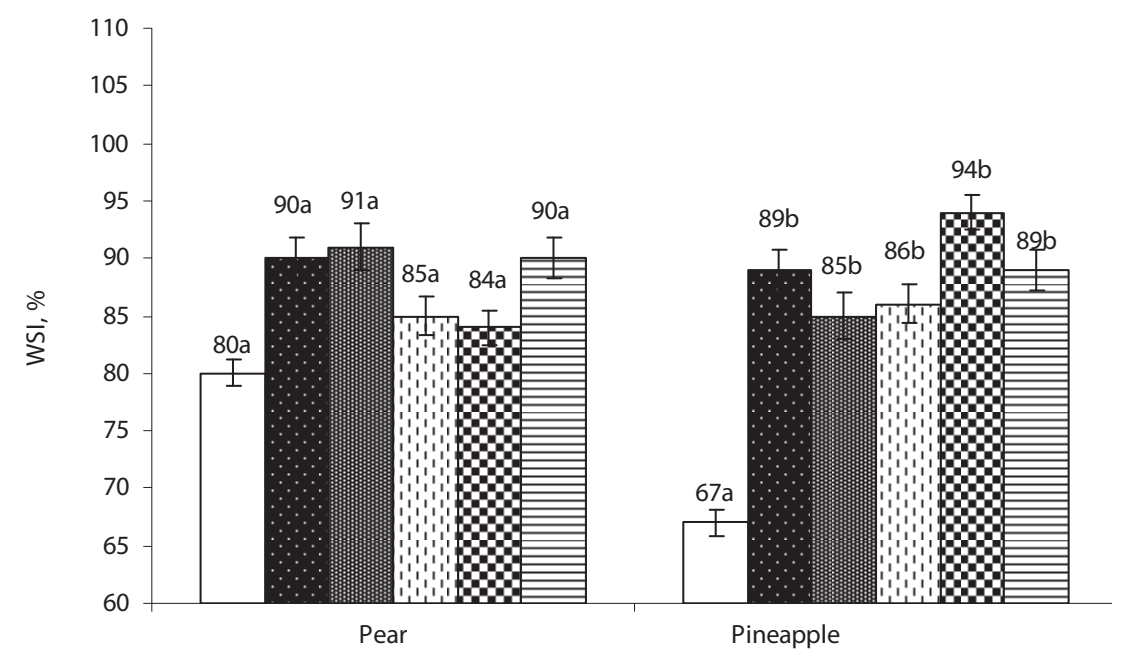

Fig. 1. Water solubility indices of freeze-dried fruit.

The same letters indicate values that are not significantly different at $\alpha=0.05$

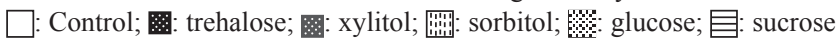

Regardless of the osmoactive compound applied, dehydration reduced WAI (Fig. 2). The decrease in WAI reached about $65 \%$ in respect to the control in the case of freeze-dried pineapple with trehalose, and the smallest effect was observed when xylitol was used.

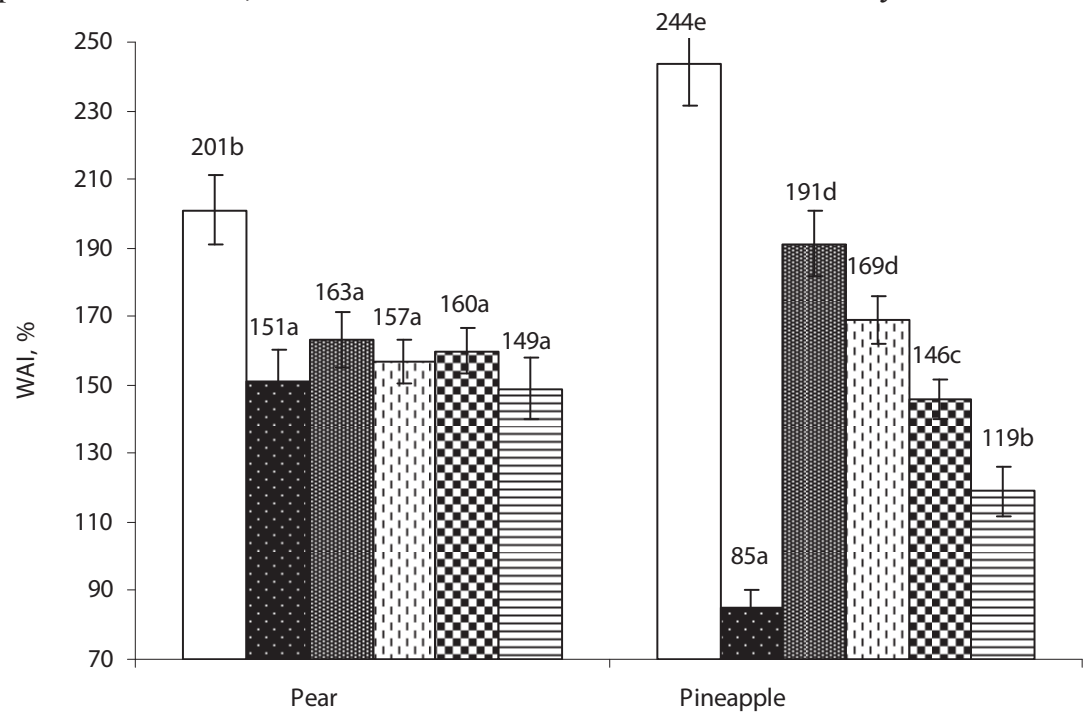

Fig. 2. Water absorption indices of freeze-dried fruit

The same letters indicate values that are not significantly different at $\alpha=0.05$

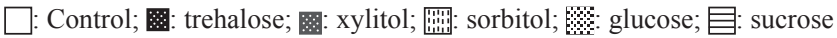


Higher molecular weight of osmoactive compound in solutions (aw $=0.90)$ contributed to a decline in the WAI in pineapple. The reduction of water absorption (WAI) for samples dehydrated in high molecular weight osmoactive substance can be interpreted in terms of saturation of outer hydrophilic groups of lyophilized fruit with osmoactive compounds (LEWICKI \& LENART, 2007).

During dehydration, the penetration of the osmoactive substance into the tissue structures of the material is observed, which causes a change of the chemical composition of the dried material.

According to PROTHON (2003), decrease of WAI can result from a decrease in the porosity of the material caused by the saturation of intercellular spaces and cell walls with osmoactive sucrose.

The influence of the composition of solutions used for osmotic dehydration of freezedried fruit samples was analysed for their ability to bind fat (Fig. 3).

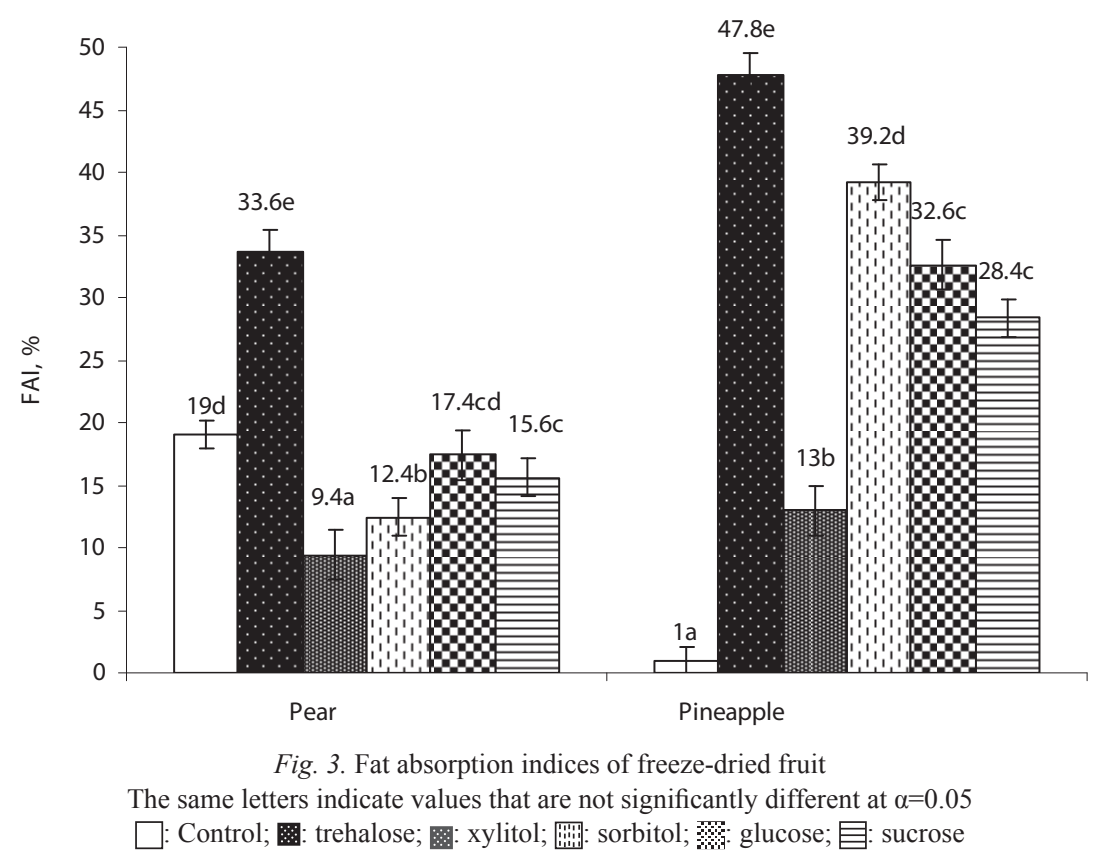

Fruit pretreated with trehalose solution showed an approximately $77 \%$ and nearly 50 fold increase in FAI in the case of pears and pineapples, respectively. In the case of lyophilized pear, conducting dehydration in other osmotic solutions than trehalose caused a decrease in the FAI index from $9 \%$ (glucose) to $50 \%$ (xylitol). The control sample of freeze-dried pineapple bound fat to a very low degree $(1 \%)$, and after the use of osmotic dehydration, a significant increase was demonstrated. Statistically significant differences $(\alpha=0.05)$ were found in the FAI depending on the osmoactive compounds used.

Freeze-dried pineapples dehydrated in trehalose and sorbitol solutions, as well as pears dehydrated in trehalose solution showed a high FAI. A high capacity to absorb fat and negative heat of dissolution of sorbitol make pears and pineapples useful for the production of low-caloric high-fat confectionery custards or ice-cream desserts. 
The specific surface area of dehydrated and lyophilized samples was determined using water vapour with $\mathrm{a}_{\mathrm{w}} \sim 0.01-0.35$. The application of pretreatment using various osmoactive compounds increased the specific surface area. All tested osmoactive compounds used for pears and pineapples affected its value in the same order, that is: control $\leq$ sorbitol $<$ trehalose $<$ glucose $<$ xylitol $<$ sucrose (Fig. 4).

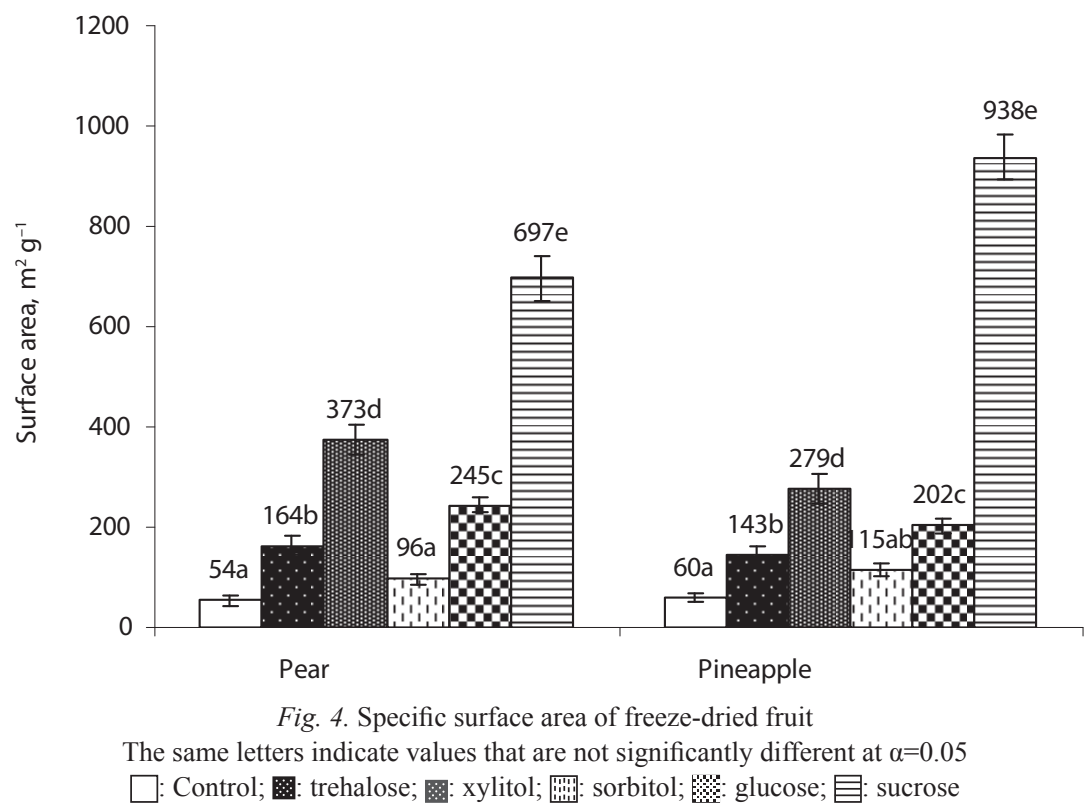

Specific surface areas for control samples were between $50-60 \mathrm{~m}^{2} \mathrm{~g}^{-1}$. Osmoactive sucrose contributed significantly to the development of surface area of freeze-dried pear $\left(\mathrm{S}_{\mathrm{BET}}=\right.$ $\left.697 \mathrm{~m}^{2} \mathrm{~g}^{-1}\right)$ and pineapple $\left(\mathrm{S}_{\mathrm{BET}}=938 \mathrm{~m}^{2} \mathrm{~g}^{-1}\right)$. Dehydration using various osmoactive compounds (except sorbitol) contributed to significant differences in the specific surface area of the freezedried fruit $(\alpha=0.05)$. The use of sorbitol in osmoactive solutions did not lead to any statistically significant differences $(\alpha=0.05)$ as compared to the samples of freeze-dried fruit.

CiurzyńsKa and Lenart $(2007,2010 \mathrm{a})$ studied the sorption properties of lyophilized strawberries subjected to osmoactive dehydration in sucrose and corn syrup solutions (DE 30-35). They demonstrated a decrease in the monomolecular layer (or $\mathrm{S}_{\mathrm{BET}}$ ) during osmotic dehydration in a sucrose solution. The most probable reason for the decrease in the capacity of the monolayer is that a whole strawberry is impenetrable to sucrose. In our own study, for most samples for which an increase was observed, the material was destined for dehydration free of the natural barrier (skin) to osmotic substances and had a uniform shape (cubes).

Freeze-dried pear and pineapple dehydrated in trehalose and/or sucrose solutions showed a weaker sorption of water vapour at $\mathrm{a}_{\mathrm{w}}=0.93$. Lyophilizates with trehalose were quite stable, reaching the equilibrium moisture content on the 4th day. Osmoactive solutions of sorbitol and/or xylitol made the fruit lyophilizates more susceptible, because they adsorbed more water vapour than the control samples. Sorption kinetic curves at $\mathrm{a}_{\mathrm{w}}=0.93$ for pear (Fig. 5B) and pineapple (Fig. 5A) control samples had a similar shape in terms of dynamics and quantity of adsorbed water vapour to their lyophilizates dehydrated in the glucose solution. 

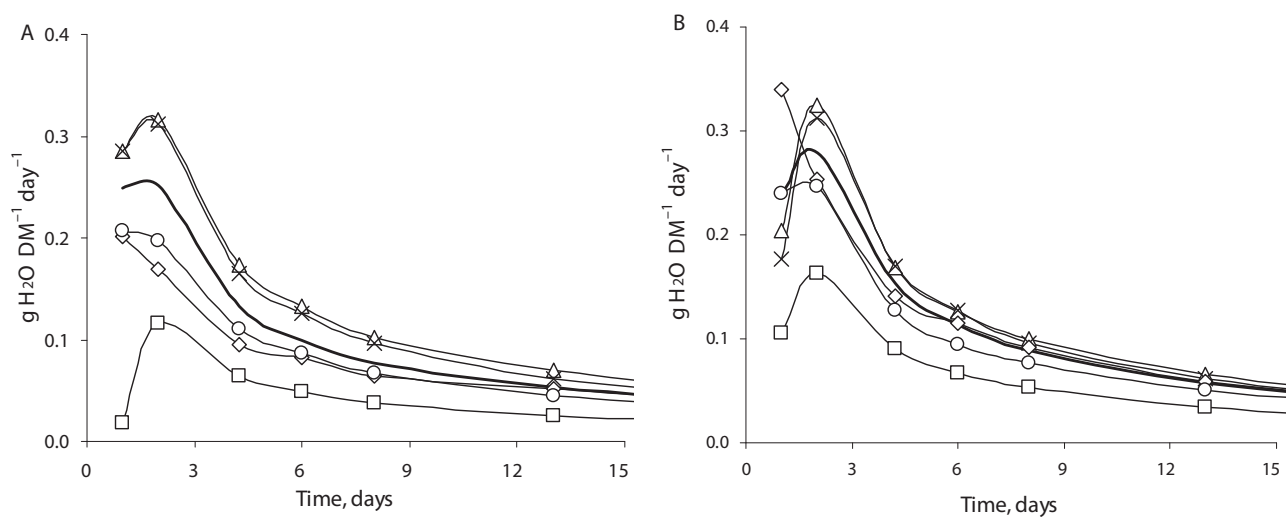

Fig. 5. Sorption curves for lyophilized pineapple (A) and pear (B) at $\mathrm{a}_{\mathrm{w}}=0.93$ $\longrightarrow$ : Control; $\multimap-$ : trehalose; $\neg-$ : xylitol; $\multimap$ : sorbitol; $\diamond$ : glucose; $\multimap$ - : sucrose

At water activity of $\mathrm{a}_{\mathrm{w}}=0.63$, the largest amount of water vapour was adsorbed by the fruit dehydrated in sorbitol solution and by the control samples (Fig. 6). Fruit osmotically dehydrated in sucrose and glucose solutions were the least susceptible to the impact of water vapour. Freeze-dried fruit tested at $\mathrm{a}_{\mathrm{w}}=0.63$ reached the equilibrium moisture content after two days.
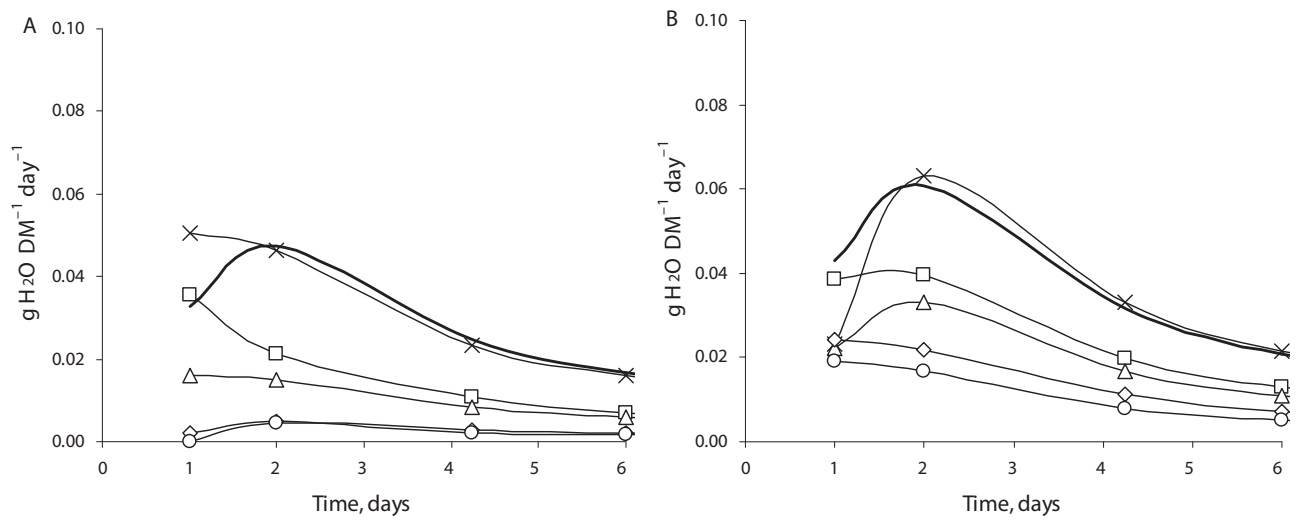

Fig. 6. Sorption curves for lyophilized pineapple (A) and pear (B) at $\mathrm{a}_{\mathrm{w}}=0.63$

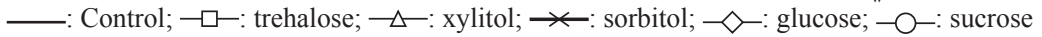

According to JANOwICZ and co-workers (2006), osmotic dehydration in solutions of glucose, sucrose, and starch syrup (DE 30-35) reduced the amount of adsorbed water vapour in whole freeze-dried strawberries. Those authors showed that lower molecular weight osmoactive compound produced more sloppy curves in the initial phase of sorption. The sorption curves for freeze-dried (control) samples and samples pre-dehydrated in the glucose solution were similar in their shapes. 
CIURZYŃSKA and LeNART (2010b) observed identical sorption dynamics in samples of fruit pre-dehydrated in a glucose solution and freeze-dried. According to those authors, the similar sorption kinetic curves resulted from a high glucose content naturally present in fruit.

Regardless of the substance used for osmotic dehydration, the lyophilized fruit absorbed lower amounts of water during rehydration than the control samples. The fruit dehydrated in xylitol and sorbitol solutions had the best rehydrated properties (Fig. 7).
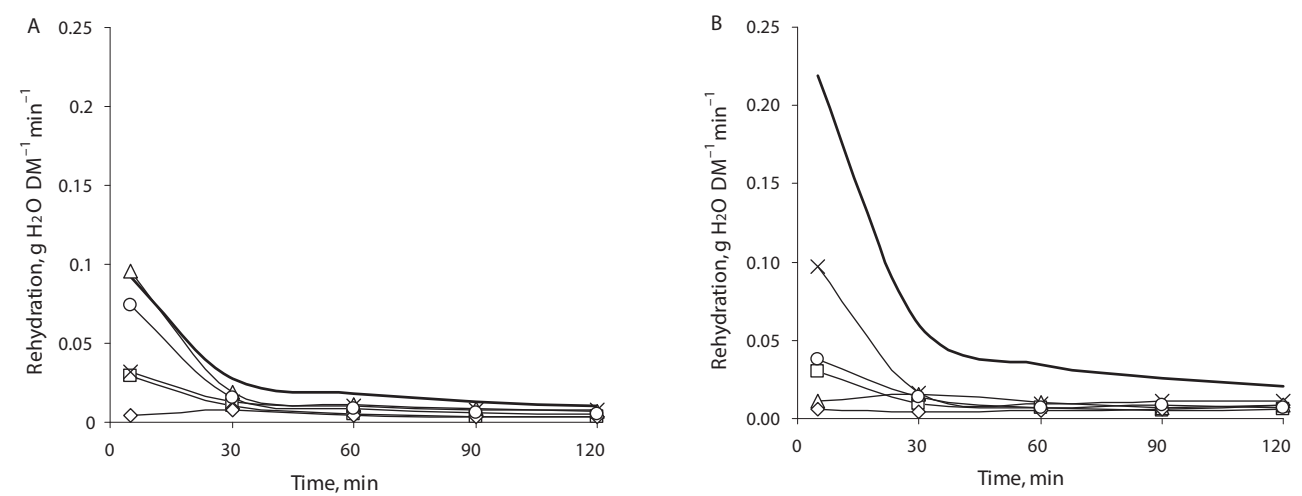

Fig. 7. Curves of pineapple (A) and pear (B) rehydration $\longrightarrow$ : Control; $\multimap-$ : trehalose; $\multimap-$ : xylitol; $\rightarrow$ : sorbitol; $\diamond-$ : glucose; $-\bigcirc$ : sucrose

CIURZYŃSKA and LENART (2009) analysed strawberries osmotically dehydrated in glucose and sucrose solutions before lyophilization. Lyophilized osmotically pre-dehydrated strawberries were less rehydrated than fruit only lyophilized. A similar relationship for dried pineapple dehydrated in sucrose solutions was reported by RASTOGI and RAGHAVARAO (2004).

According to LEWICKI (1998) and LEWICKI and co-workers (1998), the osmoactive compound altered the cell membrane permeability and, as a result, rehydrated samples absorbed water slowly compared to the samples untreated with osmotic dehydration.

According to CiURZYŃSKA and LeNART (2008), osmoactive compound penetrating into deeper tissue structures caused swelling of cells located in deeper layers, while cells in the surface layers were damaged. Further damage to those cells was caused by crystallization of the osmoactive compound. Destruction of cells either disturbed or completely suppressed the recovery of the original structure of the tissue. Easier penetration of the osmoactive compound of low molecular weight, for instance glucose, contributed to minor damage at the cellular level. TZEE LEE and co-workers (2006) demonstrated a relationship between the reconstruction of the structure of the plant material and the kind of compound used during rehydration.

The functional properties of lyophilized fruit (pretreatment osmotic dehydration) depend on the tissue structure of the material, the properties of the osmotic substance and its interaction with the ingredients of the dried material.

\section{Conclusions}

The dehydration carried out with osmoactive sweeteners, that is, sorbitol, xylitol, and trehalose, allowed the use of the lyophilized dried products as natural flavouring agents for dietetic foods of reduced calorific value, stabilising their colour and eliminating factors 
stimulating periodontitis. Consumption of dried products enriched with sorbitol, xylitol, and trehalose could contribute to the supplementation of dietary products, particularly for diabetics. The support of that thesis, however, requires further specialized physicochemical analyses of dehydrated fruit, their bioavailability, and their impact on the human body.

Preserving dehydrated raw materials by means of freeze-drying can contribute to a greater use of these technologies in the food industry.

\section{References}

Anderson, R.A., Conway, H.F., Pfeifer, V.F. \& Griffin, L.E.J. (1969): Gelatinisation of corn grits by roll and extrusion cooking. Cereal Sci. Today, 14, 4-8.

Ciurzyńska, A. \& Lenart, A. (2007): Wpływ rodzaju substancji osmotycznej na adsorpcję pary wodnej przez liofilizowane truskawek (The influence of osmotic substance type on adsorption of steam by the lyophilised strawberry). Inż. Rol., 5, 93.

Ciurzyńska, A. \& Lenart, A. (2008): Wpływ odwadniania osmotycznego na zmiany struktury liofilizowanych truskawek (Influence of osmotic dehydration on changes in the structure of freeze-dried strawberries). Acta Agrophys., 12, 613-624.

CiURzYŃSKA, A. \& LENART, A. (2009): The influence of temperature on rehydration and sorption properties of freezedried strawberries. Croat. J. Food Sci. Tech., 1, 5-23.

CiURzyŃSKA, A. \& LENART, A. (2010a): Rehydration and sorption properties of osmotically pretreated freeze-dried strawberries. J. Food Eng., 97, 267-274.

CiURzYŃSKA, A. \& LENART, A. (2010b): Structural impact of osmotically pretreated freeze-dried strawberries on their mechanical properties. Int. J. Food Prop., 13(5), 1134-1149.

Ciurzyńska, A., Lenart, A. \& KaWA, P. (2013): Influence of chemical composition and structure on sorption properties of freeze-dried pumpkin. Dry Technol., 31(6), 655-665.

Comesan, J.F., Correa, A. \& Sereno, A.M. (2001): Water activity in sorbitol or xylitol + water and sorbitol or xylitol + sodium chloride + water systems at $20^{\circ} \mathrm{C}$ and $35^{\circ} \mathrm{C}$. J. Chem. Eng. Data, 46, 716-719.

Hammami, C. \& Rene, F. (1997): Determination of freeze-drying process variables for strawberries. J. Food Eng., 32 , $133-154$.

JANOwicz, M., LENART, A. \& IDZIKOwSKA, W. (2006): Wpływ parametrów obróbki osmotycznej na kinetykę Adsorpcji pary wodnej przez liofilizowane truskawki (Influence of osmotic pretreatment on the kinetics of water vapour adsorption by freeze-dried strawberries). Acta Agrophys., 8(4), 851-886.

Kopera, M. \& Mitek, M. (2007): Wpływ procesu odwadniania osmotycznego na zawartość polifenoli w suszach gruszkowych (Pyrus communis i Pyrus pyrifolia) (Effect of osmotic dehydration on polyphenols content in dried pears (Pyrus communis and Pyrus pyrifolia)). Żywność Nauka Technologia Jakość, 5(54), 213-221.

Lewicki, P.P. \& Lenart, A. (2007): Osmotic dehydration of fruit and vegetable. -in: Mujumdar, A.S. (Ed.) Handbook of industrial drying. Taylor \& Francis, Boca Raton, FL, pp. 665-669.

Lewicki, P.P. (1998): A three parameter equation for food moisture sorption isotherms. J. Food Process. Eng., 21, $127-144$.

Lewicki, P.P., Witrowa-Rajchert, D., Pomarańska-Łazuka, W. \& Nowak, D. (1998): Rehydration properties of dried onion. Int. J. Food Prop., 1, 275-290.

Marani, C.M., Agnelli, M.E. \& Mascheroni, R.H. (2007): Osmo-frozen fruits: mass transfer and quality evaluation. J. Food Eng., 79(4), 1122-1130.

Moura, C.P., Masson, M.L. \& Yamamoto, C.I. (2005): Effect of osmotic dehydration in the apple (P. malus) varieties Gala, Gold and Fugi. Therm. Eng., 4(1), 46-49.

Pęrosławska-Garstka, A. \& Lenart, A. (2010): Wybrane właściwości fizyczne miąśszu dyni odwadnianej osmotycznie w roztworach cukrów (Some physical properties of pumpkin tissue osmotically dehydrated in sugar solutions). Acta Agrophys., 16(2), 413-422.

Prothon, F. (2003): Combined dehydration methods: From fresh fruit to high-quality ingredients. PhD Thesis, Lund Institute of Technology, Lund, Sweden. 188 pages.

Rastogi, N.K. \& Raghavarao, K. (2004): Mass transfer during osmotic dehydration of pineapple: considering Fickian diffusion in cubical configuration. LWT-Food Sci. Technol., 37(1), 43-47.

Rutkowski, A. \& KozŁowska, H. (1981): Preparaty żywnościowe z białka roślinnego (Food preparations of vegetable protein). WNT, Warsaw, pp. 318-322.

Acta Alimentaria 48, 2019 
RüEGG, M. (1980): Calculation of the activity of water in sulphuric acid solutions at various temperature. $L W T-$ Food Sci. Technol., 13, 22-24.

RząCA, M. \& Witrowa-RAJCHERT, D. (2007): Wpływ techniki suszenia oraz warunków przechowywania na właściwości rekonstytucyjne i higroskopijne suszu jabłkowego (Influence of drying technique on optical properties of dried apple slices). Acta Agrophys., 9(2), 471-479.

Shishehgarha, F., Makhlouf, J. \& Ratti, C. (2002): Freeze-drying characteristics of strawberries. Dry Technol., 20, $131-145$.

Tzee LeE, K., FARID, M. \& NGUANG, S.K. (2006): The mathematical modeling of the rehydration characteristics of fruit. J. Food Eng., 72, 16-23.

WŁodARCZYK-Stasiak, M. \& JAMroz, J. (2008): Analysis of sorption properties of starch-protein extrudates with the use of water vapour. J. Food Eng., 85, 580-589. 